\title{
Experimental Investigation of Delta Phase Precipitation in Inconel 625 Superalloy Aged at 550, 625 and $725^{\circ} \mathrm{C}$
}

\author{
Renato Baldan ${ }^{a, *}$ (1), Antonio Augusto Araujo Pinto da Silva ${ }^{(10, \text { Tiemi Manfio Tanno }}$,
}

Eliara Torres da Costa ${ }^{b}$, João Victor Negri Brentegani ${ }^{b}$, Antonio Augusto Couto ${ }^{c}$ []

\author{
${ }^{a}$ Universidade Estadual Paulista (Unesp), Câmpus Experimental de Itapeva, Rua Geraldo Alckmin, 519, \\ Vila Nossa Senhora de Fátima, 18409-010, Itapeva, SP, Brasil \\ ${ }^{b}$ Universidade Federal de Itajubá (UNIFEI), Instituto de Engenharia Mecânica (IEM), Avenida BPS, \\ 1303, 37500-903, Itajubá, MG, Brasil \\ ${ }^{c}$ Universidade Presbiteriana Mackenzie, Escola de Engenharia, Rua da Consolação, 930, \\ Consolação, 01302-907, São Paulo, SP, Brasil
}

Received: October 1, 2019; Revised: December 01, 2019; Accepted: February 17, 2020

The $\delta$ is an important stable phase that replaces the metastable $\gamma$ " in the microstructure of Inconel 625 superalloy. The present work aims to investigate the kinetic of $\delta$-phase precipitation in the microstructure of Inconel 625 nickel-based superalloy aged at 550,625 and $725^{\circ} \mathrm{C}$ up to $1000 \mathrm{~h}$. Aging temperatures were chosen based on the thermodynamic simulation using JMatPro software which indicated that this phase is stable at temperatures below $905^{\circ} \mathrm{C}$. Microstructure of the heat-treated samples was analyzed via SEM/EDS and microhardness evolution was performed by Vickers microhardness tests. The results have shown that the samples aged at $550{ }^{\circ} \mathrm{C}$ (all times), $625{ }^{\circ} \mathrm{C}$ (all times) and $725^{\circ} \mathrm{C}$ up to $200 \mathrm{~h}$ did not presented microstructural evidences of $\delta$ precipitation. However, samples aged at $725^{\circ} \mathrm{C}$ for 500 and $1000 \mathrm{~h}$ clearly presented an acicular $\delta$-phase precipitated mainly at the grain boundaries. It was noted changes in the microhardness at different aging time and temperatures probably due to the presence of $\gamma$ " and/or $\delta$ phases. The sample aged at $625^{\circ} \mathrm{C}$ for $1000 \mathrm{~h}$ presented the highest microhardness value $(333 \pm 10 \mathrm{HV})$.

Keywords: Inconel 625, delta phase, aging, microstructure, superalloy.

\section{Introduction}

Inconel 625 is a Ni-based superalloy widely used specially in aerospace components, nuclear and maritime industries due to its high corrosion, stress and fatigue resistance and its excellent weldability in a wide range of temperature from cryogenic $\left(\sim 150{ }^{\circ} \mathrm{C}\right)$ up to $982{ }^{\circ} \mathrm{C}^{1-6}$.

The microstructure of Inconel 625 superalloy is mainly composed by a $\gamma$ matrix (Ni solid solution with addition of $\mathrm{Cr}, \mathrm{Mo}, \mathrm{Nb}$ and other elements) and hardener phases such as carbides and $\gamma$ ". The $\mathrm{MC}, \mathrm{M}_{23} \mathrm{C}_{6}$ and $\mathrm{M}_{6} \mathrm{C}$ carbides formed during the solidification and/or heat-treatments are stable even at high temperatures ${ }^{7}$. Both $\gamma$ " and $\delta$ phases are known to form in the microstructure of the Inconel 625 superalloy when it is exposed at high temperatures for extended periods of time (i.e., hundreds to thousands of hours $)^{6}$. The body-centered tetragonal $\mathrm{D}_{22} \gamma$ " $\left(\mathrm{Ni}_{3} \mathrm{Nb}\right)$ is a metastable phase which precipitates in the early stages of aging heat treatments at low temperatures $\left(550 \text { to } 750{ }^{\circ} \mathrm{C}\right)^{8}$. The precipitation of the orthorhombic and more stable $\mathrm{D} 0_{\mathrm{a}} \delta\left(\mathrm{Ni}_{3} \mathrm{Nb}\right)$ phase during aging heattreatments at high temperatures $\left(650-900{ }^{\circ} \mathrm{C}^{8},>750{ }^{\circ} \mathrm{C}^{9}\right.$, $700-760{ }^{\circ} \mathrm{C}^{10}$ ) for long times is also possible in the microstructure of Inconel 625 superalloy where precipitation strengthening by $\gamma$ " occurs ${ }^{2-4,6}$. Other intermetallic phases such as $\mu, \gamma^{\prime}$ and $\mathrm{Ni}_{2}(\mathrm{Cr}, \mathrm{Mo})$ were also been reported to appear in the microstructure of this alloy ${ }^{11,12}$.

*e-mail: renatobaldan@gmail.com
Mu et. $a l^{13}$ have studied the effects of $\mathrm{Nb}$ on $\delta$ phase precipitation and the tensile properties in cast alloy Inconel 625 solutioned at $1200{ }^{\circ} \mathrm{C}$ for $1 \mathrm{~h}$ (air cooling) and aged at $700{ }^{\circ} \mathrm{C}$ for up to $10000 \mathrm{~h}$. They have shown that volume fraction of the $\delta$ precipitation increases with both the aging time and $\mathrm{Nb}$ content. The effect of $\mathrm{Nb}$ content on the fraction of the $\delta$ phase corresponds to its effect on the $\mathrm{Nb}$ segregation degree. Shaikh et al. ${ }^{14}$ have shown the influence of precipitation of different phases in the microhardness of Inconel 625 superalloy solutioned at $1200^{\circ} \mathrm{C}$ for $1 \mathrm{~h}$ (water quenching) and aged at 625,700 and $760^{\circ} \mathrm{C}$ for intervals of time ranging from 1 to $335 \mathrm{~h}$. They reported that peak hardening is around $110 \mathrm{~h}$ at $760^{\circ} \mathrm{C}$ and $170 \mathrm{~h}$ at $700^{\circ} \mathrm{C}$. Malej et.al ${ }^{7}$ have studied the effect of aging heat-treatments at $6500^{\circ} \mathrm{C}$ up to $2000 \mathrm{~h}$ in the in hot-rolled Inconel 625 superalloy. Microstructural analysis by light and scanning electron microscopes showed the precipitation of intermetallic $\gamma "\left(\mathrm{Ni}_{3} \mathrm{Nb}\right)$ phase in the $\gamma$ matrix and $\delta\left(\mathrm{Ni}_{3} \mathrm{Nb}\right)$ phase with $\mathrm{M}_{23} \mathrm{C}_{6}$ secondary carbides at the grain boundaries.

Based on the influence of phase transformation that can occur in the microstructure of the Inconel 625 superalloy at different conditions of heat-treatment and the scarce of studies on the $\delta$ phase precipitation in the microstructure of Inconel 625 superalloy $^{15}$, the aim of this work is to evaluate the microstructural changes in the solutioned and aged samples of Inconel 625 superalloy at different conditions of time and temperature with special focus on the analysis of $\delta$-phase precipitation. 


\section{Experimental Procedure}

Inconel 625 bars were forged, annealed $\left(800^{\circ} \mathrm{C} / 2 \mathrm{~h} /\right.$ air cooling) and cut by electrical discharge machining technique. The chemical composition of the alloy was measured with the aid of an atomic emission spectrometry with inductively coupled plasma (ICP-AES). Thermodynamic simulations were performed using the JMatPro software (Ni-database) and the measured composition of the alloy. Inconel 625 samples were solutioned in argon atmosphere at $1150{ }^{\circ} \mathrm{C}$ for $2 \mathrm{~h}$ (water quench) and aged in argon atmosphere at 550,625 and $725^{\circ} \mathrm{C}$ from $24,48,72,200,500$ and $1000 \mathrm{~h}$ (air cooling). The aging temperatures were chosen based on the thermodynamic simulation which indicates that $\delta$ phase is stable at temperatures below $905^{\circ} \mathrm{C}$.

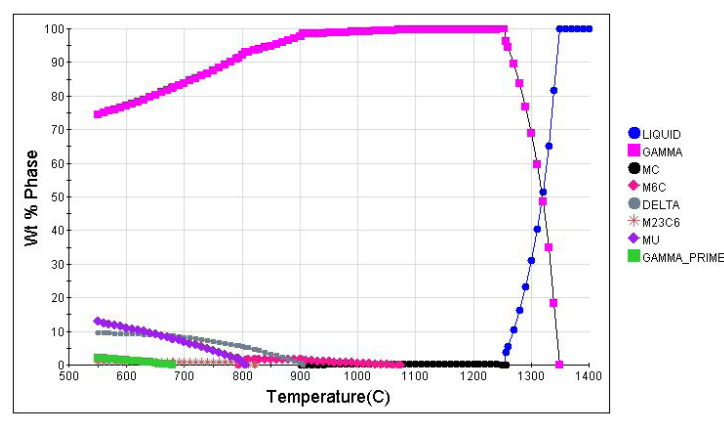

Figure 1. Thermodynamic simulation of phase fraction (wt. \%) as a function of temperature for Inconel 625 superalloy.

Table 1. Simulation of the phases (wt. \%) as a function of aging temperature for Inconel 625 superalloy.

\begin{tabular}{cccc}
\hline $\begin{array}{r}\text { Temperature }\left({ }^{\circ} \mathrm{C}\right) \rightarrow \\
\text { Phases } \downarrow\end{array}$ & 550 & 625 & 725 \\
\hline$\gamma$ & $74.6 \%$ & $78.6 \%$ & $85.5 \%$ \\
\hline$\mu$ & $12.9 \%$ & $10.2 \%$ & $5.8 \%$ \\
\hline$\delta$ & $9.5 \%$ & $9.2 \%$ & $7.7 \%$ \\
\hline$\gamma$ & $2.0 \%$ & $1.0 \%$ & $0.0 \%$ \\
\hline $\mathrm{M}_{23} \mathrm{C}_{6}$ & $1.0 \%$ & $1.0 \%$ & $1.0 \%$ \\
\hline
\end{tabular}

For microstructural characterization, the as-cast and heat-treated samples were hot mounted in resin, grounded with $\mathrm{SiC}$ paper up to \#2400 and polished with colloidal silica suspension (OP-S). The microstructural characterization was performed in a conventional scanning electron microscopy (SEM) model EVO MA15 from Carl Zeiss with EDS model X Flash 610 from Bruker. The Vickers microhardness tests were performed in the equipment from TIME with loading of $1,961 \mathrm{~N}$ for 20 seconds. At least 15 random measurements were performed in each sample and the mean value with standard deviation were calculated.

\section{Results and Discussion}

\subsection{Chemical analysis and thermodynamic simulation}

The simulations were made according to the measured composition of Inconel 625 superalloy (wt.\%): $21.5 \mathrm{Cr}$, 9.0Mo, 3.6Nb, 2.5Fe, 0.25Mn, 0.2 Ti. 0.2Al, 0.05C, Ni (balance). Figure 1 shows the thermodynamic simulation of phase fraction (wt. \%) as a function of temperature. It should be noted that $\gamma$ " phase is metastable and then is not present in the results of the simulation. The chosen solution temperature of $1150{ }^{\circ} \mathrm{C}$ is lower than the melting range of the alloy $\left(\mathrm{T}_{\text {solidus }}=1250{ }^{\circ} \mathrm{C}\right.$ and $\left.\mathrm{T}_{\text {liquidus }}=1350{ }^{\circ} \mathrm{C}\right)$ and with only $\gamma(99.7$ wt.\%) and MC carbides ( 0.3 wt.\%) as stable phases. Table 1 shows the stable phases at the aging temperatures of this work. It can be highlighted that the $\mathrm{M}_{23} \mathrm{C}_{6}$ carbide is the only carbide stable and the amount of $\gamma$ increases whilst the amount of $\mu, \delta$ and $\gamma^{\prime}$ decreases with the rising of temperature. Finally, the $\gamma$ ' solvus temperature of Inconel 625 alloy is $680^{\circ} \mathrm{C}$ and consequently this phase is not stable at aging temperature of $725^{\circ} \mathrm{C}$.

\subsection{Microstructural characterization of the alloys}

Figure 2a shows the micrograph of Inconel 625 superalloy forged + annealed + solutioned at $1150{ }^{\circ} \mathrm{C}$ for $2 \mathrm{~h}$. It can be seen the equiaxial polycrystalline grains, carbides mainly at the grain boundaries and pores. The EDS analysis in the carbide region of this sample (Figure 2b) shows that it is rich in $\mathrm{Mo}$ and $\mathrm{Nb}$, which agrees with the literature ${ }^{8,16}$ and also with the thermodynamic simulation, which gives the

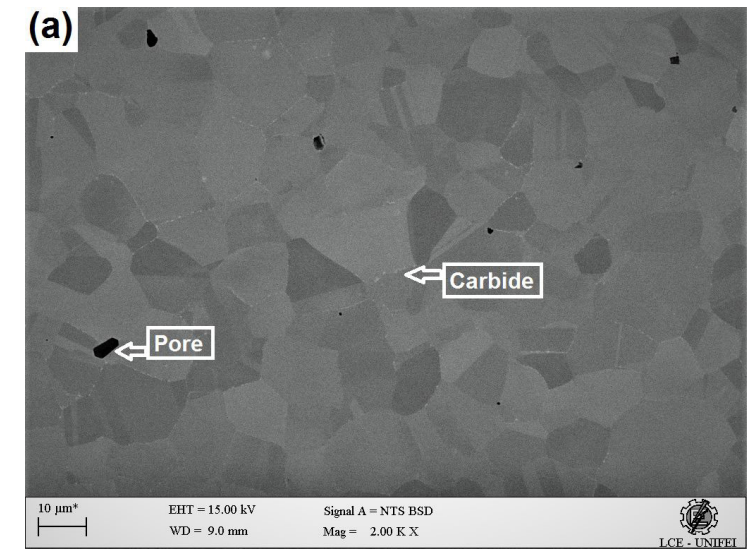

(b)

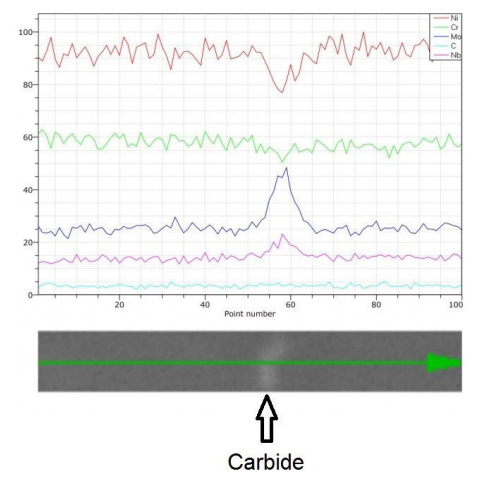

Figure 2. Inconel 625 superalloy forged, annealed $\left(800^{\circ} \mathrm{C} / 2 \mathrm{~h} /\right.$ air cooling) and solutioned at $1150{ }^{\circ} \mathrm{C}$ for $2 \mathrm{~h}$ : (a) Microstructure (SEM/BSE) and (b) Compositional profile of the carbide at the grain boundary region. 
equilibrium composition of $\mathrm{MC}$ carbides at this temperature as (wt.\%): $85.5 \mathrm{Nb}, 10.4 \mathrm{C}, 2.3 \mathrm{Mo}, 1.6 \mathrm{Ti}, 0.2 \mathrm{Cr}$.

The SEM/BSE micrographs of the samples aged at $550{ }^{\circ} \mathrm{C}$ (all times), $625^{\circ} \mathrm{C}$ (all times) and $725{ }^{\circ} \mathrm{C}$ up to $200 \mathrm{~h}$ presented no microstructural evidences related with $\delta$-phase precipitation. However, the samples aged at $725^{\circ} \mathrm{C}$ for $500 \mathrm{~h}$ (Figure 3a) and $1000 \mathrm{~h}$ (Figure 3b) clearly presented a new phase in the microstructure. Literature shows that the precipitation of $\gamma$ " and $\delta$ phases occurs between $550{ }^{\circ} \mathrm{C}$ to $750{ }^{\circ} \mathrm{C}$ and $750{ }^{\circ} \mathrm{C}$ to $980{ }^{\circ} \mathrm{C}$, respectively ${ }^{2-4,6}$ and the $\delta$ particles have needle, plate, as well as globular morphologies ${ }^{17-20}$, but the first one in the more common. Based on this, the acicular-morphology phase present in the microstructure of the alloys suggests the $\delta$-phase precipitation, initially in grain boundaries and then in all microstructure. At sufficiently long exposure to high temperatures, the metastable $\gamma$ " phase dissolves, which result in an increase of local concentration of $\mathrm{Nb}$ in the matrix, contributing to the nucleation and growing of stable $\delta\left(\mathrm{Ni}_{3} \mathrm{Nb}\right)$ particles mainly at $\{111\}$ planes, which are the primary slip planes in the FCC metals ${ }^{21}$. Finally, increasing the $\mathrm{Nb}$ concentration is found to increase the driving force to form the $\delta$ phase, so it is excepted the fraction of the $\delta$ phase can be controlled by changing the $\mathrm{Nb}$ content ${ }^{13,22}$.

Due to the low amounts of $\mathrm{Al}$ and $\mathrm{Ti}$, the volume fraction of $\gamma^{\prime}$ phase is either low (at $550{ }^{\circ} \mathrm{C}$ and $625^{\circ} \mathrm{C}$ ) or none (at $725^{\circ} \mathrm{C}$ ), as shown in Table 1 . In this sense, the $\gamma^{\prime}$ phase can also be present in the microstructure (at $550{ }^{\circ} \mathrm{C}$ and $625^{\circ} \mathrm{C}$ ) but has only minor effect on the properties of Inconel 625 superalloy and it was not observed in the micrographs of the present work.
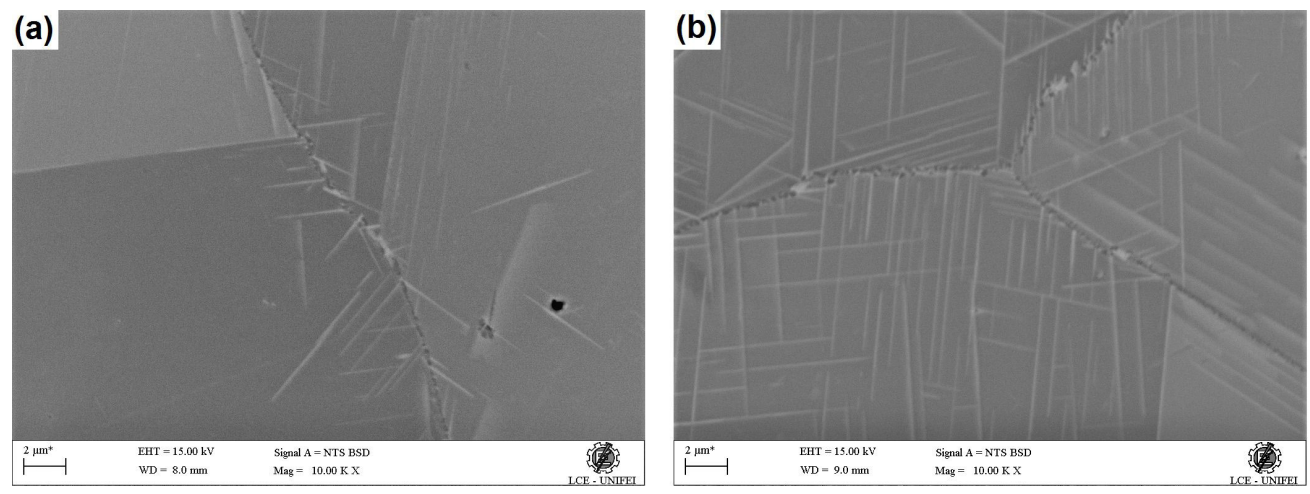

Figure 3. SEM/BSE micrographs of Inconel 625 superalloy aged at $725^{\circ} \mathrm{C}$ for (a) $500 \mathrm{~h}$ and (b) $1000 \mathrm{~h}$.
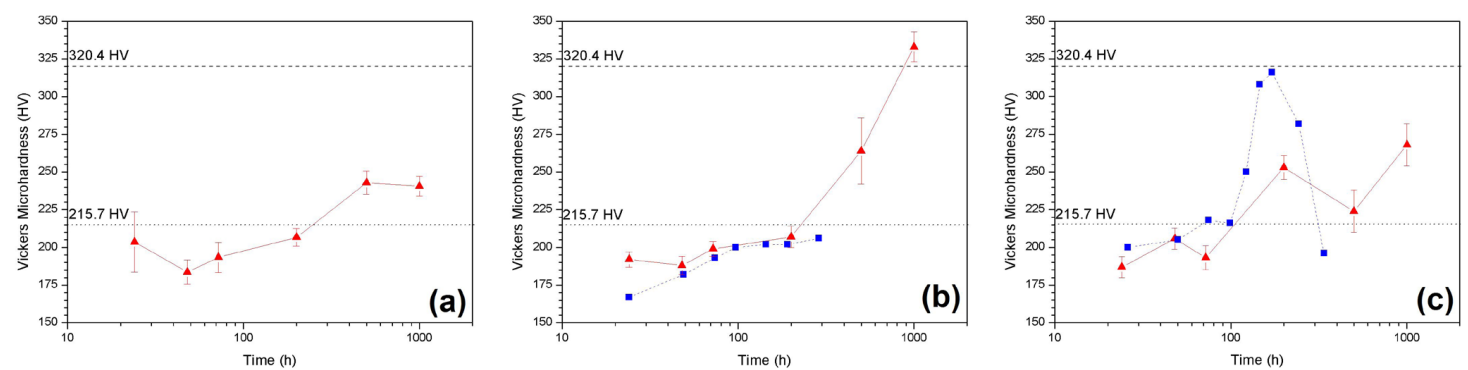

Figure 4. Vickers microhardness values of Inconel 625 superalloy as function of aging time at (a) 550 , (b) 625 , and (c) $725^{\circ} \mathrm{C}$. The triangles are the values found in the present work while the squares are from Shaikh et al. ${ }^{14}$. 
of the alloy. The values found at $1000 \mathrm{~h}$ did not change significantly when compared with the alloy aged at $500 \mathrm{~h}$. At $625^{\circ} \mathrm{C}$ (Figure 4b) it can also be noted that an increasing of the microhardness with the aging time up to $1000 \mathrm{~h}$ $(333 \pm 10 \mathrm{HV})$ is probably due to the nanometric precipitation of $\gamma$ " metastable phase. The values at $625^{\circ} \mathrm{C}$ are in good agreement with the values obtained by Shaikh et al. ${ }^{14}$.

Figure $4 \mathrm{c}$ shows the microhardness values for Inconel 625 superalloy obtained by Shaikh (heat-treated at $\left.700{ }^{\circ} \mathrm{C}\right)^{14}$ and in this work (heat-treated at $725^{\circ} \mathrm{C}$ ). At $700{ }^{\circ} \mathrm{C}$ the results obtained by Shaikh et al. ${ }^{14}$ showed an important increasing in the microhardness for times close to $200 \mathrm{~h}$ of heat treatment followed by a decreasing at $500 \mathrm{~h}$. However, the values found by Shaikh et al. ${ }^{14}$ for the peak of microhardness and the subsequent decreasing are substantially high compared with the values found in this work. For times above $500 \mathrm{~h}$ in this work the microhardness starts to increase again probably because the metastable phase $\gamma$ " transforms into $\delta$ phase as observed in the microstructure of the alloy at $725^{\circ} \mathrm{C}$ for $500 \mathrm{~h}$ (Figure $3 \mathrm{a}$ ).

It is well known that the increasing of the amount of brittle $\delta$-phase was found to have undesirable effects on the mechanical behavior of the Inconel 625 superalloy, especially in the high-temperature ductility and fracture toughness ${ }^{2,4,9,10,23-25}$. However, fine acicular $\delta$ phase precipitated at the grain boundaries prevents the grain growth and restricts grain boundaries sliding, contributing to the mechanical properties of the alloy, specially fracture ductility and microhardness ${ }^{22,26}$.

\section{Conclusion}

In the present work the microstructural evolution of the Inconel 625 superalloy forged, annealed at $800{ }^{\circ} \mathrm{C} / 2 \mathrm{~h} /$ air cooling, solutioned at $1150{ }^{\circ} \mathrm{C}$ for $2 \mathrm{~h}$ and aged at 550 , 625 and $725^{\circ} \mathrm{C}$ up to $1000 \mathrm{~h}$ was performed with focus on the analysis of $\delta\left(\mathrm{Ni}_{3} \mathrm{Nb}\right)$ phase formation. The main results of this work are:

- According to the thermodynamic simulation, only $\gamma$ and $\mathrm{MC}$ carbides are the stable phases at the solution temperature of $1150{ }^{\circ} \mathrm{C}$;

- The SEM/BSE micrographs of the Inconel 625 superalloy forged + annealed + solutioned at $1150{ }^{\circ} \mathrm{C}$ for $2 \mathrm{~h}$ showed equiaxial polycrystalline grains, carbides rich in $\mathrm{Nb}$ and Mo mainly in the grain boundaries and pores;

- $\quad$ No microstructural evidences related with $\delta$-phase precipitation were found in the micrographs of the samples aged at $550{ }^{\circ} \mathrm{C}$ (all times), $625{ }^{\circ} \mathrm{C}$ (all times) and $725^{\circ} \mathrm{C}$ up to $200 \mathrm{~h}$. However, the microstructure of the samples aged at $725^{\circ} \mathrm{C}$ for 500 and $1000 \mathrm{~h}$ clearly presented this phase;

- The microhardness of the Inconel 625 alloy forged + annealed + solutioned at $1150{ }^{\circ} \mathrm{C}$ for $2 \mathrm{~h}$ were $216 \pm 4 \mathrm{HV}$. The sample aged at $625^{\circ} \mathrm{C}$ for $1000 \mathrm{~h}$ presented the highest microhardness value $(333 \pm 10 \mathrm{HV})$. It was noted changes in the microhardness at different aging time and temperature of the heat treatment probably due to the precipitation of $\gamma$ " and/or $\delta$ phases.

\section{Acknowledgements}

The authors would like to thank The State of São Paulo Research Foundation - FAPESP - (Process 2018/07802-9)

\section{References}

1. Ghosh S, Yadav S, Das G. Study of standard heat treatment on mechanical properties of Inconel 718 using ball indentation technique. Mater Lett. 2008;62(17-18):2619-22.

2. Floreen S, Fuchs GE, Yang WJ. Superalloys 718, 625, 706 and various derivatives. In: Loria EA. International Symposium on Superalloys 718, 625, 706 and Various Derivatives Sponsored by the Minerals, Metals \& Materials Society and Cosponsored by ASM International and National Association of Corrosion Engineers; 1994 June 26-29; Pittsburgh. Proceedings. Pittsburgh: The Minerals, Metals \& Materials Society; 1994.

3. Suave LM, Cormier J, Villechaise P, Soula A, Hervier Z, Bertheau $\mathrm{D}$, et al. Microstructural evolutions during thermal aging of Alloy 625: impact of temperature and forming process. Metall Mater Trans, A Phys Metall Mater Sci. 2014;45A(7):2963-82.

4. Sundararaman M, Mukhopadhyay P, Banerjee S. Precipitation of the $\delta$ - Ni3 $\mathrm{Nb}$ phase in two nickel base superalloys. Met Trans A. 1968;19A:453-65.

5. Idell Y, Levine LE, Allen AJ, Zhang F, Campbell CE, Olson $\mathrm{GB}$, et al. Unexpected beta-phase formation in additivemanufactured Ni-based super-alloy. JOM. 2016;68(3):950-9.

6. Lass EA, Stoudt MR, Williams ME, Katz MB, Levine LE, Phan $\mathrm{TQ}$, et al. Formation of the $\mathrm{Ni} 3 \mathrm{Nb}$ d -phase in stress-relieved inconel 625 produced via laser powder-bed fusion additive manufacturing. Metall Mater Trans, A Phys Metall Mater Sci. 2017;48(11):5547-58

7. Malej S, Medved J, Batič BŠ, Tehovnik F, Godec M. Microstructural evolution of inconel 625 during thermal aging. Metalurgija. 2017;56:319-22

8. Sundararaman M, Mukhopadhyay P, Banerjee S. Carbide precipitation in nickel base superalloys 718 and 625 and their effect on mechanical properties, superalloys 718, 625, 706 Var. Pittsburgh: The Minerals, Metals \& Materials Society; 1997. p. 367-78.

9. Mostafaei A, Hughes ET, Hilla C, Stevens EL, Chmielus M. Data in brief data on the densi fi cation during sintering of binder jet printed samples made from water- and gas-atomized Alloy 625 powders. Data Brief. 2017;10:116-21.

10. Lim YS, Kim DJ, Hwang SS, Kim HP, Kim SW. M23C6 precipitation behavior and grain boundary serration in Ni-based Alloy 690. Mater Charact. 2014;96:28-39.

11. Sundararaman M, Kumar L, Prasad GE, Mukhopadhyay P, Banerjee S. Precipitation of an intermetallic phase with Pt 2 Mo-Type structure in Alloy 625. Metall Mater Trans, A Phys Metall Mater Sci. 1999;30(1):41-52.

12. Mittra J, Dubey JS, Banerjee S. Acoustic emission technique used for detecting early stages of precipitation during aging of Inconel 625. Scr Mater. 2003;49(12):1209-14.

13. $\mathrm{Mu} \mathrm{Y}$, Wang $\mathrm{C}$, Zhou W, Zhou L. Effect of $\mathrm{Nb}$ on $\delta$ phase precipitation and the tensile properties in cast alloy IN625. Metals (Basel). 2018;8(2):86.

14. Shaikh MA, Ahmad M, Shoaib KA, Akhter JI, Iqbal M. Precipitation hardening in Inconel 625. Mater Sci Technol. 2000;16(2):129-32.

15. Singh JB, Verma A, Jaiswal DM, Kumar N, Patel RD, Chakravartty JK. Rejuvenation of service exposed ammonia cracker tubes of cast Alloy 625 and their re-use. Mater Sci Eng A. 2015;644:254-67.

16. Shankar V, Bhanu Sankara Rao K, Mannan S. Microstructure and mechanical properties of Inconel 625 superalloy. J Nucl Mater. 2001;288(2-3):222-32. 
17. Sundararaman M, Mukhopadhyay P, Banerjee S. Precipitation of the delta-Ni3 $\mathrm{Nb}$ phase in two nickel base superalloys. Metall Trans, A, Phys Metall Mater Sci. 1988;19(3):453-65.

18. Muzyka DR, Maniar GN. Effects of solution treating temperature and microstructure on the properties of hot-rolled 718 alloy. Met. Eng. Q. 1969;9:23-37.

19. Zhu ZY, Sui Y, Dai AL, Cai YF, Xu LL, Wang ZX, et al. Long term aging treatment impact on ultralow iron Alloy 625 intergranular corrosion property. Preprints. 2017:2017090149. http://dx.doi.org/10.20944/preprints201709.0149.v1.

20. Ding YT, Gao YB, Dou ZY, Gao X, Liu DX, Jia Z. Precipitation behavior of delta phase of deformation induced GH3625 superalloy hot-extruded tube. Chin Shu Hsueh Pao. 2017;53:695-702.

21. Jambor M, Bokůvka O, NovýF, Trško L, Belan J. Phase transformations in nickel base superalloy inconel 718 during cyclic loading at high temperature. Production Engineering Archives. 2017;15:15-8.
22. Singh JB, Sundararaman M, Mukhopadhyay P, Prabhu N. Effect of ternary $\mathrm{Nb}$ additions on the stability of the $\mathrm{D}_{22}$ structure of the Ni3V phase. Scr Mater. 2003;48(3):261-7.

23. Liu D, Zhang X, Qin X, Ding Y. High-temperature mechanical properties of Inconel-625: role of carbides and delta phase. Mater Sci Technol. 2017;33(14):1610-7.

24. Zhang H, Li C, Liu Y, Guo Q, Li H. Precipitation behavior during high-temperature isothermal compressive deformation of Inconel 718 alloy. Mater Sci Eng A. 2016;677:515-21.

25. Mittra J, Banerjee S, Tewari R, Dey GK. Fracture behavior of Alloy 625 with different precipitate microstructures. Mater Sci Eng A. 2013;574:86-93.

26. Qi H, Azer M, Ritter A. Studies of standard heat treatment effects on microstructure and mechanical properties of laser net shape manufactured INCONEL 718. Metall Mater Trans, A Phys Metall Mater Sci. 2009;40(10):2410-22. 